Ritstýrð grein birt 28. nóvember 2018

\title{
Notkun spjaldtölva í námi og kennslu grunnskólanemenda á yngsta stigi með áherslu á læsi
}

\author{
Jóhanna Porvaldsdóttir, Guðmundur Engilbertsson og Hermína Gunnpórsdóttir
}

\author{
Abstract Um höfundana About the authors Heimildir
}

Pessi grein er byggðá gögnum úr eigindlegri rannsókn sem gerð var í tveimur íslenskum grunnskólum á höfuðborgarsvæðinu vorið 2014. Meginmarkmið rannsóknarinnar var að öðlast skilning á notkun spjaldtölva í námi og kennslu grunnskólanemenda á yngsta stigi með hliðsjón af upplýsinga-, miðla- og tæknilæsi. Gagnaöflun var tvípæett og fólst annars vegar í vettvangsathugunum í skólunum tveimur par sem spjaldtölvur voru notaðar og hins vegar voru tekin viðtöl við kennarana að loknum vettvangsathugunum. Skólar og kennarar sem tóku pátt í rannsókninni voru valdir vegna reynslu peirra af notkun spjaldtölva í námi og kennslu á yngsta stigi grunnskóla. Grunnskólarnir bættu báđir spjaldtölvum við tæknibúnað sinn veturinn 2012 til 2013. Niðurstöðum pessarar rannsóknar ber að taka með peim fyrirvara að hún nær eingöngu til fimm kennara í tveimur skólum og að ekki var fylgst með hópi nemenda lengur en sem nam einni kennslustund. Pær benda pó til pess að spjaldtölvur geti stutt nám og kennslu með ýmsum hætti. Sem dæmi pá virðist notkun spjaldtölva opna kennurum leið til að auka notkun upplýsingatækni í námi og kennslu á yngsta stigi og gefa tækifæri til að auka pátt netsins, vefefnis og samfélagsmiðla í námi ungra nemenda. Pær gefa aukin tækifæri til að efla upplýsinga- og miðlalæsi og tæknilæsi meðal yngstu nemendanna og auka fjölbreytni í skólastarfi, t.d. með fjölda smáforrita sem sérstaklega eru gerð til að pjálfa ýmsa færnipætti í námi, en einnig með möguleikum sem einfalda myndatökur, hljóðupptökur, kvikmyndatökur og samsetningu miðlunarpátta.

Efnisorð: Spjaldtölvur, upplýsingalæsi, miðlalæsi, tæknilæsi, yngsta stig grunnskóla.

\section{Inngangur}

Stafrænir miðlar og netheimar verða æ ríkari páttur í daglegu lífi flestra og fartækni ${ }^{1}$ hefur haft mikil áhrif á samskiptahætti og menningu (Hrefna Arnardóttir, 2007; Sólveig Jakobsdóttir, Torfi Hjartarson og Bergpóra Dórhallsdóttir, 2014). Margir telja snjallsíma og spjaldtölvur vera tákn um nýja tíma og að innleiðing peirra í skólastarf geti auðgað menntun og auðveldað kennurum að koma til móts við fjölbreyttar parfir nemenda og nýjar áherslur í námi og kennslu (Clark og Luckin, 2013; Ómar Örn Magnússon, e.d.; Sólveig Jakobsdóttir, Skúlína H. Kjartansdóttir, Helga Ó. S. Dórormsdóttir og Ragnheiður L. Pálsdóttir, 2012). Töluverð umræða hefur verið um notkun fartækni, og pó einkum spjaldtölva, í skólastarfi. Umræðan hefur m.a. snúist um að nemendur purfi enn frekar en ádur að fá tækifæri til að nota tækni og fjölbreytta miðla í skólanum enda sé stafræn miðlun orðin stór hluti af lífi peirra utan skólans (Light og Pierson, 2012; Luckin o.fl., 2012; Snowman og McCow, 2012).

\footnotetext{
Fartækni (e. mobile technology) vísar til tækja eins og farsíma og spjaldtölva, p.e. tækja sem auðvelt er að bera með sér og veita tækifæri til gagnvirkni og samskipta (Schofield, West og Taylor, 2011, bls. 16-18).
} 
Samhliða pessari umræðu endurspegla áherslur stefnumótunaraðila náms og kennslu pessar breytingar. Tæknin hefur m.a. breytt umhverfi lesturs og ritunar (Horton, 2008; RAND, 2002; Smolin og Lawless, 2003), læsishugtakið hefur fengið víðari merkingu og gert er ráð fyrir að upplýsingatækni sé fléttað saman við aðrar námsgreinar, öllum nemendum til hagsbóta (Mennta- og menningarmálaráđuneytið, 2013). Dessi sýn gerir kröfur um breytingar á skólastarfi og margir stefnumótunaraðilar skólastarfs á 21. öldinni telja mikilvægt að nám og kennsla próist 1 takt við örar breytingar á tækni og samfélagi (European Commission, 2018; Fullan, 2013).

Spjaldtölvur eru nýleg tæki í skólastarfi og enn sem komið er hafa fáar rannsóknir verið gerðar á áhrifum peirra á nám og kennslu enda er lítil reynsla komin af notkun peirra í skólunum (sjá pó t.d. Guðrúnu Gunnarsdóttur, 2015; Sólveigu Jakobsdóttur o.fl., 2012). Hins vegar hafa margar rannsóknir verið gerðar á upplýsingatækni í skólastarfi og byggist pessi rannsókn á peim pekkingargrunni og fræðum sem fjalla um samfélagsbreytingar, öra tæknipróun og nýjar áherslur í námi og kennslu. Í rannsókninni sem hér verður kynnt var leitast við að svara eftirfarandi rannsóknarspurningu: Hvernig nota starfandi kennarar spjaldtölvur á yngsta stigi grunnskólans og hvers konar notkun miðar sérstaklega að pví að efla upplýsinga- og miðla- og tæknilæsi?

\section{Fræðilegt samhengi}

\section{Tæknivæðing og lykilhæfni}

Tölvu- og tæknivæðing hefur náð fótfestu alls staðar í samfélaginu. Í skólum eru tölvur sjálfsögð tæki og notaðar daglega við ýmiss konar samskipti, undirbúning kennslu, upplýsingaöflun og upplýsingamiðlun og við margs konar verkefna- og námsefnisgerð. Frá síðustu aldamótum hafa fartölvur, margmiðlunartækni, stafræn tækni og farsímar breiðst hratt út ásamt háhraðatengingum, práðlausu neti og örum vexti netsins (Hrefna Arnardóttir, 2007; Sólveig Jakobsdóttir o.fl., 2014). Hnattvæðingin hefur stuðlað að margvíslegum tengingum milli jarðarbúa og ör tæknipróun hefur einfaldað tengsl milli aðila óháð staðsetningu peirra í heiminum. Almenningur nýtir sér fartækni í æ ríkari mæli, en hún gerir fólki kleift að eiga gagnvirk samskipti á ferðinni (Schofield, West og Taylor, 2011). Bent hefur verið á að ný tækni kalli á markvissa innleiðingu í skólastarf til pess að hún nýtist sem best (Fullan, 2013; Light og Pierson, 2012; Snowman og McCow, 2012).

Í menntaáæetlun Evrópusambandsins er lögð áhersla á að hver einstaklingur stundi nám allt líf¡ð (e. lifelong learning). Getan til að takast á við síbreytilegan hnattvæddan heim er lykilhæfni sem vinna parf að. Einn lykilpátta í áætluninni er hæfni til að nýta sér stafræna tækni (e. digital competence). Nemendum er ætlað að pjálfa sig í gagnrýninni notkun upplýsinga og öðlast góða pekkingu á upplýsingasamfélaginu með pað fyrir augum að geta nýtt sér tæknina við hvers konar iðju og störf. Nemendur verða pví að læra á tækin og kunna að nota pau til að sækja, meta og geyma upplýsingar, framleiða og kynna efni, kynnast leiðum til að skiptast á upplýsingum, miðla efni til annarra og taka pátt í samvinnuverkefnum á netinu (European Commission, 2018).

\section{Skólastarf og kennsluhættir}

Degar nýjungar, eins og pær sem felast í upplýsingatækni, eru innleiddar í skólastarf parf að leggja áherslu á viðhorfsbreytingar og skólamenningu sem einkennist af samvinnunámi og markvissri tækninotkun í námi og kennslu (Fullan og Donnelly, 2013). Slíkar breytingar eru hins vegar ekki sjálfgefnar og í pví sambandi bendir Fullan (2007) á að mikilvægt sé að viðhorf, kennsluhættir og námsefni próist í félagslegu samhengi ef skólamenning á að próast og breytast. Pess vegna sé pað lykilatriði að kennarar læri saman á vettvangi og ígrundi starfshætti og fræði. Dannig geti peir proskast saman og tileinkað sér breytingar. 
Rannsóknin Starfshcettir í grunnskólum var gerð í 20 grunnskólum hér á landi á árunum 2009 til 2011 (Anna Kristín Sigurðardóttir og Gunnhildur Óskarsdóttir, 2012). Tilgangur hennar var m.a. að búa til gagnabanka um skólastarf á Íslandi og voru fjölmargir pættir í skólastarfi skoðaðir. Vettvangsathuganir í 383 kennslustundum leiddu í ljós að tafla (krítartafla eða tússtafla) væri vinsælasta kennslutækið, notað í 39\% kennslustunda og væri til staðar í nánast öllum kennslustofum. Tölvur voru í mörgum kennslustofum en oftast var um eina tölvu að ræða og hún ætluð kennara. Tölvur voru notaðar í um 20\% kennslustunda og í flestum tilfellum var um val eða stöðvavinnu аð ræða og hlutfallslega voru pær sjaldnast notaðar á yngsta stigi. Skjávarpi var notaður í 13\% kennslustunda og margmiðlunarefni í samtals 22 kennslustundum, eða í 6\% af peim 383 kennslustundum sem athugaðar voru. Dessar niðurstöður eru byggðar á nokkurra ára gömlum gögnum en gefa vísbendingar um takmarkaða möguleika nemenda til að nýta sér upplýsingatækni í námi á viðkomandi tímabili.

\section{Læsi í tæknivæddum heimi}

Læsi er grunnpáttur við pekkingaröflun af flestu tagi en tækninýjungar hafa breytt samskiptaumhverfi samtímans og leitt til nýrra skilgreininga á læsishugtakinu. Í skilgreiningu mennta- og menningarmálaráđuneytisins á hugtakinu læsi kemur fram að pað felist í ,að búa yfir pekkingu og leikni til að skynja, skilja, túlka, gagnrýna og miðla texta í víðum skilningi til að mæta kröfum samfélagsins og einstaklingsins. Með texta er átt við ritmál, myndmál, talmál og önnur kerfi tákna“ (Mennta- og menningarmálaráðuneytið, 2010). Dessi skilgreining er grunnurinn að peim hugmyndum sem einkenna læsi sem einn grunnpátta menntunar í aðalnámskrá grunnskóla (Mennta- og menningarmálaráduneytið, 2013).

Í nútímasamfélagi er stafræn samskiptatækni yfirleitt talin mikilvægur páttur daglegs lífs. Almenn notkun tölva og tækninýjunga sem auðvelda aðgengi að netinu hefur áhrif á skólastarf og fjölbreyttir möguleikar til miðlunar hafa leitt af sér fleiri tegundir læsis, t.d. stafrænt læsi/ tölvulæsi (e. digital literacy/computer literacy), miðlalæsi (e. media literacy) og upplýsingalæsi (e. information literacy) (Horton, 2008; RAND, 2002; Smolin og Lawless, 2003). Í aðalnámskrá grunnskóla kemur fram að styðja purfi læsi í pessum víða skilningi og að líta beri á tölvur sem öflug tæki sem nota megi til fjölpættrar merkingarsköpunar, t.d. í myndvinnslu og til margmiðlunar auk pess að nota pær sem ritvinnslu- og reikningsverkfæri (Mennta- og menningarmálaráðuneytið, 2013).

Tæknilæsi felur í sér leikni og kunnáttu til að nota tækjabúnað við að miðla efni og afla pekkingar. Tæknilæs einstaklingur skilur hvernig tæknin virkar og kann að nýta sér fjölbreytta möguleika tækjanna við viðfangsefni í námi eða vinnu (Smolin og Lawless, 2003). Upplýsingalæsi felur í sér hæfni til að sækja upplýsingar, flokka pær og meta á gagnrýninn hátt. Með miðlalæsi er átt við pekkingu og færni sem fæst með pví að læra um fjölbreytta miðla, pekkja notagildi peirra, læra að nýta sér pá og skilja áhrif peirra á menningu og lýðræði. Á vissan hátt mætast pessi hugtök og skarast hvað varðar skilgreiningar og umfjöllun og í pessari grein kjósa höfundar að fjalla í sameiningu um upplýsinga- og miðlalæsi. Gert er rád fyrir að pegar nemendur pjálfist í tækni-, upplýsinga- og miðlalæsi aukist hæfni peirra til að tileinka sér pekkingu, umskrifa hana og skapa nýja. Einnig er gert ráð fyrir að peir öðlist hæfni til að miðla pekkingu og reynslu á skapandi og fjölbreyttan hátt í samræmi við eðli tækninnar og stafrænt umhverfi (Horton, 2008; Mennta- og menningarmálaráđuneytið, 2013; Stefán Jökulsson, 2012).

\section{Möguleikar tengdir spjaldtölvum í skólastarfi}

Spjaldtölvur eru létt og meðfærileg tæki með snertiskjá og pær er hægt að nota á fjölbreyttan hátt. Spjaldtölvur ganga fyrir endurhlaðanlegum rafhlöðum, geta geymt töluvert magn upplýsinga í minni og gefa svipaða notkunarmöguleika og venjulegar borð- og fartölvur (Tablet computer, 2013). Pær nýtast til miðlunar hljóð- og myndefnis, geta tekið upp myndir og hljóð, eru hljóð- 
ver, bókasöfn, hljóðfæri og samskiptatæki svo fátt eitt sé nefnt. Spjaldtölvur hafa almennt einfalt notendaviðmót, auðvelt er að bera pær á sér og færa á milli staða og pær ræsa sig upp á skömmum tíma. Pær má nota nánast alls staðar og hvar sem práđlaust netsamband er í boði geta notendur tengst netinu. Fjölbreyttir og skapandi notkunarmöguleikar spjaldtölva henta pví vel í skólastarfi (Tamim, Borokhovski, Pickup, Bernard og El Saadi, 2015) en pykja nýtast nemendum einna best pegar peir hafa eigin tæki til umráða og geta pannig prófað sig áfram án pess að tímamörk hafi áhrif á notkunina (Ómar Örn Magnússon, e.d.). Greiðara aðgengi að spjaldtölvum hefur aukið áhuga á að nota möguleika fartækni í námi og kennslu.

Með spjaldtölvum er nemendum unnt að afla upplýsinga, vinna úr peim og setja fram nýjar, deila peim og geyma gögn sem geta sýnt framvindu og afrakstur í námi á einfaldan og fljótvirkan hátt. Taka má viðtöl, búa til kvikmyndir og tónlist, vinna efnið og deila með skólafélögum á styttri tíma og auðveldari hátt en áður hefur pekkst (Clark og Luckin, 2013). Með fartækni aukast pannig tækifæri nemenda til að nýta sér upplýsinga- og samskiptatækni utan hefðbundinna tölvuvera. Með pví að auðvelda aðgengi og pekkingu á tækninni má próa nýjar leiðir sem stafrænt og rafrænt umhverfi býður upp á (Light og Pierson, 2012).

\section{Netið og fartækni - notkun í skólastarfi}

Nettengdar tölvur eru tæki sem nota má til samskipta, pekkingaröflunar, framsetningar og birtingar. Með notkun tækninnar og fjölbreyttum kennsluaðferðum geta gefist tækifæri til að kenna nemendum aðferðir við öflun, úrvinnslu og miðlun upplýsinga á skapandi, áhugaverðan og fjölbreyttan hátt. Námið hvílir pá á læsi, tjáningu og miðlun með hjálp verkfæra á borð við tölvur og net (Cohen, Manion, Morrison og Wyse, 2010; Snowman og McCow, 2012).

Rannsóknir sem lúta að áhrifum upplýsinga- og samskiptatækni á nám og kennslu sýna að upplýsingatækni getur haft jákvæð áhrif á pekkingu, leikni og hæfni nemenda (Balanskat, 2009). Margir telja einnig að notkun tækninnar við nám og kennslu stuðli að aukinni fjölbreytni og efli sjálfstæði, ábyrgð og áhuga nemenda (Balanskat, 2009; Vuorikari, Garoia og Balanskat, 2011). Flestir kennarar eru sammála um mikilvægi upplýsinga- og samskiptatækni við próun kennsluhátta og telja einnig að notkun tækninnar við nám og kennslu stuðli að nemendamiðaðri kennslu og efli gagnrýna hugsun nemenda (European Commission, 2013; Reykjavíkurborg, 2014; Sólveig Jakobsdóttir o.fl., 2012). Sífellt auðveldara verður að koma á beinu sambandi við hvern sem er og pannig getur fartæknin skapað tækifæri til margs konar samvinnu og samskipta. Fjöldi smáforrita, sem sérstaklega eru gerð með nám og kennslu í huga, hefur verið búinn til og próast samhliða nýjum tækjum og tækni. Stöðug endurgjöf og sjón- og hljóðrænir pættir geta verið áhugahvetjandi og líklegir til að auka einbeitingu og sjálfsöryggi nemenda á öllum aldri pví nemendur læra hratt eftir óformlegum leiðum (ICT Cluster, 2009; Redecker o.fl. 2011). Notkun tækninnar getur haft mikil áhrifá nám en víða eru tækninýjungar og nýstárlegar námsleiðir vannýttar og vanmetnar (Luckin o.fl., 2012). Degar á framangreint er litið hlýtur að teljast mikilvægt að kanna vel hvernig fartækni getur gagnast námi og kennslu og leita leiða til að próa starfshætti sem færa skólastarf nær tíðaranda 21. aldarinnar.

\section{Rannsóknaraðferð}

Í rannsókninni sem hér um ræđir var rýnt í reynslu einstaklinga og pví pótti við hæfi að nota eigindlega rannsóknaraðferð, en pá er byggt á sýn peirra á ákveðið viðfangsefni, upplifun, viðhorf og reynslu (Sigurlína Davíðsdóttir, 2013). Fyrir valinu varð rannsóknarsniðið tilviksrannsókn (e. case study). Tilvikið sem hér var rannsakað er notkun spjaldtölva í námi og kennslu grunnskólanemenda á yngsta stigi í tveimur íslenskum grunnskólum og efling upplýsinga-, miðla- og tæknilæsis. Rannsóknarspurningin er svohljóðandi: Hvernig nota starfandi kennarar spjaldtölvur á yngsta stigi grunnskólans og hvers konar notkun miðar sérstaklega að pví að efla upplýsinga- og miðla- og tæknilæsi? 
Gagna var aflað í mars 2014. Dátttakendur voru valdir með markmiðsúrtaki (e. purposive sampling) en pá velur rannsakandi pátttakendur sem hann telur nýtast sér og rannsóknarefninu (Silverman, 2010). Skólar og kennarar sem tóku pátt í rannsókninni voru valdir vegna reynslu peirra af notkun spjaldtölva í námi og kennslu á yngsta stigi grunnskóla.

Í öðrum pátttökuskólanum var samkennsla tveggja árganga og í hinum hefðbundið bekkjakerfi. Grunnskólarnir bættu báđir spjaldtölvum við tæknibúnað sinn veturinn 2012 til 2013. Sá fámennari átti 15 spjaldtölvur sem ætlaðar voru fyrir kennara og 250 nemendur en sá fjölmennari átti 30 spjaldtölvur, 18 ætlaðar 520 nemendum og 12 ætlaðar kennurum til afnota í starfi.

Pátttakendur voru fimm kennarar í tveimur grunnskólum á höfuðborgarsvæðinu. Fjórir peirra voru umsjónarkennarar en sá fimmti umsjónarmaður upplýsingavers og kennari í upplýsingamennt á yngsta stigi. Kennararnir voru á aldrinum 29 til 63 ára og allir kvenkyns. Deir höfðu rúmlega sjö til 40 ára reynslu af kennslu og höfðu starfað allt að 10 ár í sama skóla. Tveir voru umsjónarkennarar í 4. bekk, einn umsjónarkennari í 2. bekk og einn hafði umsjón með 1. bekk. Tveir pátttakendanna voru úr 250 nemenda skóla en prír úr skóla með 520 nemendum.

Gagnaöflun og úrvinnsla var tvíbætt. Gerðar voru fimm vettvangsathuganir, ein hjá hverjum pátttakanda/kennara í eina kennslustund par sem spjaldtölvur voru notaðar við nám og kennslu. Tekin var staða pátttökuáhorfanda (e. participant observer) og pátttakendur pví upplýstir um ástæður og fyrirætlanir rannsakanda (Schutt, 2006). Í samvinnu við kennara voru valdar kennslustundir par sem fyrirfram var ljóst að spjaldtölvur yrðu notaðar. Útbúin voru eyðublöð sem hentuðu vel til formlegra skráninga á gögnum. Með óformlegu spjalli, áhorfi og hlustun söfnuðust gögn um aðstæður, viðfangsefni og miðlun, hvernig tæki voru notuð, sveigjanleika, sjálfstæði í vinnubrögðum, samvinnu, virkni og áhuga og hvert hlutverk kennarans var í kennslustundinni.

Pá voru tekin fimm hálf-formgerð viðtöl, eitt við hvern pátttakanda eða kennara, að loknum vettvangsathugunum. Viðtalsrammi var mótaður með hliðsjón af fræðilegri pekkingu, rannsóknarspurningu og gögnum úr vettvangsathugunum. Hann var svo endurskoðaður milli viðtala. Sem dæmi voru kennarar spurðir um pað hve oft peir notuðu spjaldtölvur við kennslu, um forpekkingu peirra á notkun tækjanna í skólastarfi og ástæðu fyrir notkuninni. Rætt var um undirbúning fyrir nemendur og foreldra, hvort og pá hvernig kennararnir teldu innleiðingu spjaldtölva bæta skólastarf, hvernig námsmati væri háttað, hvers konar smáforrit væru notuð og hvernig peir notuðu tækin til að styðja læsi. Viðtölin voru mynd- og hljóðrituð með spjaldtölvu og tók hvert peirra um 30 til 60 mínútur.

Viðtölin voru afrituð orðrétt og við gagnagreiningu voru upplýsingarnar flokkaðar í nokkur pemu til að skýra viðhorf og reynslu kennara af notkun spjaldtölva í skólastarfi með ungum nemendum. Við úrvinnslu var efninu skipt í sex pemu. Pau voru spjaldtölvur og innleiðing í skólastarf, spjaldtölvur og samfélagið, spjaldtölvur og upplýsingamennt, spjaldtölvur og kennarinn, spjaldtölvur og nemandinn og loks spjaldtölvur og upplýsinga-, miðla- og tæknilæsi. Í pessari grein verður fjallað um niðurstöður sem varða áhrif spjaldtölva á tæknilæsi og upplýsinga- og miðlalæsi.

Rannsakandi (fyrsti höfundur og sá sem safnaði gögnum) var sjálfur aðalverkfæri rannsóknarinnar enda um túlkandi eigindlega rannsóknaraðferð að ræða. Reynsla fyrsta höfundar af notkun spjaldtölva á yngsta stigi grunnskóla gaf færi á dýpri sýn pegar gagna var aflað. Veturinn 20122013 vann hann með kennara sem innleiddi spjaldtölvur í nám og kennslu í 3. bekk grunnskóla. Í bekknum voru 18 nemendur og fékk hver peirra sína spjaldtölvu sem peir notuðu daglega. Nemendurnir unnu með ýmiss konar smáforrit, kynntust netmiðlum, bjuggu til eigin vefsíðu og fengust við samvinnuverkefni með erlendum skóla svo nokkur dæmi séu nefnd. Reynsla rannsakanda nýttist einnig til að skilja betur verkefnin sem voru unnin í kennslustundunum og við greiningu gagna. Í greiningarferlinu var rannsakandi meðvitaður um að eigin reynsla og skoðanir gæu haft áhrif á túlkun gagna og vinnu við rannsóknina. 
Rannsóknin var tilkynnt til Persónuverndar og fræðsluyfirvöld í sveitarfélögum beggja skóla veittu leyfi til að hafa samband við skólastjóra. Deir fengu kynningu á viðfangsefninu, veittu sampykki sitt til rannsóknar og opnuðu leið rannsakanda að kennurunum, sem undirrituðu upplýst sampykki eftir að hafa kynnt sér eðli og framkvæmd rannsóknarinnar. Dað var mat skólayfirvalda og kennara að ekki pyrfti sérstakt sampykki foreldra, enda engum persónugreinanlegum gögnum safnað.

\section{Niðurstöður}

Til hagræðingar verða niðurstöður kynntar í tveimur undirköflum. Fyrst verður fjallað um tæknilæsi en síðan verður um notkun spjaldtölva á yngsta stigi grunnskólans út frá upplýsingaog miðlalæsi.

\section{Tæknilæsi}

prír af viðmælendunum fimm sögðu spjaldtölvur mjög gagnleg verkfæri til að efla tæknilæsi pví spjaldtölvan væri einföld, aðgengið gott og hægt að afla sér gagna, lesa, skrifa, teikna, taka myndir, búa til kvikmyndir og koma frá sér upplýsingum, allt með sama tækinu. Kennari í 2. bekk sagði spjaldtölvur hafa góð áhrif á tæknilæsi pví með tækið í höndum pjálfuðust nemendur í notkun upplýsingatækni almennt. Nemendur læri á tækin, stillingaratriði, forrit og hvernig tæki og forrit nýtast við margbreytilega verkefnavinnu nemenda. Viðmælandi í öðrum skólanum sagði nemendur á yngsta stigi nota ýmsa möguleika sem tæknin veitir. Deir vildu t.d. gjarnan taka myndir af vel heppnuðum verkefnaúrlausnum og senda til foreldra sinna.

Kennararnir sögðust finna að tæknin væri stór páttur í lífi nemenda og að oft gætu ungir nemendur kennt kennurum ýmislegt í pví sambandi pví peir væru svo óhræddir við að prófa alla möguleika. Viðmælendur sögðu flesta nemendur sína hafa aðgang að spjaldtölvu eða öðru sambærilegu tæki heima og að pað skýrði pekkingu peirra á tækjunum. Viðmælendur sögðu tæknilæsi nemenda orðið töluvert strax í 1. bekk og að nemendur pyrftu litla kennslu á tækin sjálf. Einn kennarinn lýsti kunnáttu ungra nemenda pannig að peir pekktu ákveðnar táknmyndir og ynnu svo út frá peim. Orðrétt sagði hann: „Đau vita alveg að „,settings“ er tannhjól og pá fara pau pangað og, já, pau prófa sig bara áfram.“”

Í vettvangsathugunum og í viðtölum við kennara kom fram að nemendur áttu flestir auðvelt með að nýta sér pá möguleika sem smáforritin í spjaldtölvunum buðu upp á. Deir kunnu að fara á netið og vissu að auðvelt væri að senda myndir og skjöl sín á milli. Nemendur deildu fúslega pekkingu sinni og hjálpuðust að ef hindranir urðu á vegi peirra. Nefna má að nemandi í 1. bekk, sem pekkti vel til möguleika spjaldtölvunnar og smáforrits sem unnið var með, gat leiðbeint öðrum nemendum í peim efnum. Hann áttaði sig á og benti sumum á að peir væru ekki að taka upp eins og ætlast væri til og sýndi hvernig peir gætu séð hvenær peir væru að taka upp og hvenær ekki. Hann sýndi jafnframt tveimur bekkjarfélögum hvernig ætti að nota myndavélina í spjaldtölvunni og sá á tækjum peirra að pað átti eftir að veita hljóðnema spjaldtölvunnar aðgang að forritinu sem unnið var með. Petta gat hann lagfært án vandkvæða og kenndi samnemendum pau stillingaratriði. Sambærilegt dæmi mátti greina í 4. bekk, en par komu nokkrir tækniörðugleikar upp vegna stillingaratriða og opna purfti fyrir hljóðnema í sumum spjaldtölvunum svo hljóðskrá virkaði. Nemandi kunni að laga petta og leiðbeindi öðrum nemendum við stillingar.

Við notkun sumra forrita kynntust nemendur ýmsum táknum sem leggja grunn að flóknari notkun fjölmargra forrita. Sem dæmi má nefna tákn sem eru sambærileg táknum í ritvinnsluforritinu Word og tákn er varða vistun og geymslu gagna. Sumir lærðu einnig á stillingaratriði tölvanna með pví að lesa í myndform tákna á skjáborðinu og áætla út frá útliti peirra hvernig pau væru notuð. Kennarar sögðu einfalt aðgengi að pví sem tækin bjóða upp á stuðla að pví að einstaklingar á öllum aldri gætu nýtt sér tæknina, petta væri bara ein snerting og pá opnaðist allt. Í máli eins viðmælanda kom fram að einfaldleikinn skipti afar miklu máli og allt í sambandi við 
spjaldtölvur væri svo einfalt og aðgengi auðvelt, en pað væru mikilvægir pættir pegar tölvur væru notaðar með nemendum, sérstaklega á yngsta stigi.

\section{Upplýsinga- og miðlalæsi}

Í stærðfræðitíma á vettvangi mátti sjá dæmi um vinnu nemenda sem fólst í pví að nemendur sóttu sér pekkingu á netið. Kennarinn hafði búið til kennslumyndir um reikningsaðferðir og gert efnið aðgengilegt á heimasíðu skólans. Nemendur notuðu pessar myndir til að ná tökum á nokkrum reikningsaðferðum og horfðu eins oft og hver purfti. Viðmælandi sagði petta fyrirkomulag efla upplýsingalæsi og auka sjálfstæði nemenda í námi pví peir pjálfuðust í að sækja sér pekkingu sjálfir. Kennarinn gæti pannig vísað veginn en ábyrgðin væri í höndum nemendanna sjálfra. Nemendur voru öruggir í notkun spjaldtölvunnar og vissu vel hvernig peir áttu að ná í kennslumyndirnar á heimasíðuna en fram kom að peir hefðu aldrei fengið neina sérstaka kennslu í pví.

Allir viðmælendur voru sammála um mikilvægi práðlausrar nettengingar. Annar pátttökuskólinn hafði verið með slíka tengingu í ár og hinn var nýkominn með hana. Kennararnir töluðu um að með spjaldtölvum opnuðust miklir möguleikar til náms og með tilkomu práðlausu nettengingarinnar hefðu möguleikarnir margfaldast. Eins og einn peirra sagði: ,,... eftir að við fengum pessa práðlausu tengingu varð auðvitað bara bylting ... komin með heiminn í fangið, sko“. Kennari í 1. bekk taldi frábært að hafa pó ekki væri nema eina spjaldtölvu alltaf í kennslustofunni, pá gæeti hann bara rétt fram tölvuna og látið nemendur tvo og tvo saman leita sér upplýsinga á netinu. Hann sagði unga ólæsa nemendur alveg geta fundið ákveðin gögn, myndir og pess háttar, og taldi slíka vinnu m.a. efla upplýsingalæsi nemenda.

Viðmælendur sögðu einfalt viðmót spjaldtölvunnar fyrir mynd- og hljóðupptökur opna mörg tækifæri og á vettvangi mátti sjá að skapandi forrit voru notuð við sögugerð og frásagnir af ýmsu tagi. Kennarar telja að með spjaldtölvum gefist óendanlega margir möguleikar í sambandi við sögugerð og fleira pví skylt, pví að ritun verði svo einföld fyrir alla með möguleikum sem ýmis smáforrit og jaðartæki gefi. Pannig gefist tækifæri til að hvetja pá sem ekki hafa náð tökum á rituðu máli til að nota myndmál og talað mál í ritunarverkefnum ásamt pví að tengja verkefnin við áhugasvið nemenda. Nemendur fái pannig tækifæri til að nota hugmyndaflug sitt, áhugasvið og leik, jafnframt pví að efla upplýsingalæsi, en kennararnir sögðust svo bæta við stigvaxandi kröfum um að nota einnig ritmál við túlkunina. Í vettvangsathugunum kom einnig í ljós að nemendum pykir gaman að deila afrakstri verkefna sinna hver með öðrum.

Ungir nemendur hafa frá mörgu að segja en pá skortir oft færni til að rita pað niður og segja skipulega frá. Með rafbókagerð gefst nemendum tækifæri til að nota, auk hefðbundins texta, myndir og tal máli sínu til stuðnings. Í einni vettvangsathugun rannsakanda unnu nemendur 2. bekkjar að gerð rafbóka. Peir áttu að teikna myndir í forriti og skrifa við pær eina setningu en tala svo inn á myndirnar og segja sögu. Sumir ákváðu í upphafi hvað peir ætluðu að nota margar myndir til að segja söguna og unnu út frá pví meðan aðrir skipulögðu sig á annan hátt, byrjuðu bara að teikna og létu sköpunina leiða sig áfram. Dæmi voru um að nemendur byrjuðu upp á nýtt á upplestri inn á söguna sína af pví að peim líkaði ekki pað sem peir heyrðu pegar peir hlustuðu á afraksturinn og vildu bæta vinnu sína.

Í öðru verkefni, sem fyrst og fremst var ritunaræfing, var sýnilegt að nemendur leituðu mikið hver til annars, t.d. varðandi stafsetningu, og deildu hugmyndavinnu við sögusmíði. Deir lásu upp úr sögum sínum fyrir sessunautana sem ýmist tóku undir að petta væri fyndið eða lögðu til nýjar hugmyndir sem gætu bætt söguna. Kennararnir purftu að svara ýmsum spurningum nemenda á meðan verkefnið var leyst, t.d. um möguleika á að breyta leturstærð, textagerð, bakgrunni og lit á stöfum.

Í einni vettvangsathuguninni mátti sjá nemendur vinna að sögugerð par sem peir áttu að fara á netið og sækja myndir af persónum fyrir sögurnar sínar. Peir notuðu lyklaborð og ritvinnsluforrit við sögusmíðina og pjálfuðust í að sækja og vista efni í Dropbox (gagnageymslu á netinu), en 
pessir pættir efla upplýsingalæsi. Degar völdum smáforritum er hlaðið niður á skjá spjaldtölvunnar geta nemendur með einni fingrasnertingu opnað valið efni og horft, hlustað á eða skoðað myndir og texta. Viðmælandi sagði að nemendur lærðu að táknin hefðu ákveðna pýðingu og pað gagnaðist peim vel síðar meir, pegar peir færu að nota önnur forrit. Niðurstöðurnar eru gott dæmi um pað hvernig efla má upplýsingalæsi samhliða skapandi vinnu.

Einn viðmælandi sagði að með spjaldtölvu og práðlausri tengingu við skjávarpa gæfust möguleikar til miðlunar og að upplýsingatæknin færðist með pví nær nemendum. Annar sagði að með spjaldtölvum væri aðgengi að rafrænum upplýsingum byltingarkennt. Degar vettvangsathuganirnar voru gerðar var oftast unnið með ritun, lestur, skilning og orðaforða en vinnan sem unnin var í smáforritunum kynnti fyrir nemendum nokkrar leiðir til að miðla hugarefnum sínum pví við verkefnavinnu urðu ýmist til textar, hljóðefni, myndir eða kvikmyndabútar.

Í viðtali við kennara í 2. bekk kom fram að honum pættu spjaldtölvur bæta nám pví með peim gæfist tækifæri til að gera efni lifandi og myndrænt og pað vekti áhuga og pörf nemenda fyrir að miðla upplifun sinni, segja frá eða semja sögu. Dá sögðu tveir kennarar frá fyrirhuguðu pemaverkefni um himingeiminn og töldu spjaldtölvurnar gefa færi á nýstárlegri nálgun í pví sambandi. Annar viðmælandinn lýsti pví pannig að með spjaldtölvu væri hægt að skoða himingeiminn svo myndrænt. Efnið yrði svo hreyfanlegt og líflegt, allt öðruvísi en pegar lesið væri um pað í bók.

Á vettvangi í pátttökuskólunum tveimur sáust fá dæmi um að nemendur nýttu sér fjölbreytta miðla við upplýsingaöflun í kennslustundum. Í viðtali kom pó fram að einn kennarinn notaði samfélagsmiðilinn YouTube til að auka upplýsingaflæði til foreldra. Hann stofnaði lokaðan aðgang að miðlinum og sendi foreldrum lykilorðin. Dar birti hann upptökur frá daglegu starfi í skólanum og foreldrar hófu í kjölfarið að taka upp myndir heima í samvinnu við börn sín og birta á sömu sídu.

Pátttakendur sögðust nota spjaldtölvur við nám og kennslu um pað bil einu sinni til tvisvar í viku. Deir sögðust myndu nota pær oftar og á fjölbreyttari hátt ef aðgengi að peim væri betra en báðir skólarnir áttu aðeins fá tæki ætluð kennurum og nemendum. Kennararnir sögðust vera að feta sig áfram í litlum skrefum. Deir hefðu hingað til oftast notað stærðfræðileikjaforrit en nú bætt við forritum sem gerðu nemendum kleift að tjá sig með orðum, tali og myndum.

\section{Umræða}

Í viðtölum við kennarana kemur fram að peim sýnast spjaldtölvur vera orðnar almenn eign á heimilum og að ungir nemendur séu vel færir um að nýta sér pær í ýmsum aðstæðum. Petta kemur heim og saman við pað sem hér sagði í upphafi um útbreiðslu stafrænnar tækni sem einfaldar samskipti (Hrefna Arnardóttir, 2007; Schofield o.fl., 2011; Sólveig Jakobsdóttir o.fl., 2014). Viðmælendur töldu að með spjaldtölvum sköpuðust miklir möguleikar til náms og kennslu á yngsta stigi grunnskólans og að peir ykjust enn frekar pegar háhraða nettenging bættist við. Niðurstöður ýmissa rannsókna gefa líka til kynna að notkun upplýsingatækni í námi og kennslu geti haft marga kosti pegar nútímakennsluháttum er beitt í kennslustofunni (Cohen o.fl., 2010). •ó að notkun netsamskipta og samfélagsmiðla geti ekki talist vera lýsandi fyrir starfið á vettvangi virðast nemendur búa yfir færni til að nýta sér fjölbreytta möguleika sem spjaldtölvur bjóða. Рað gefur tilefni til að ætla að ungir nemendur geti notað upplýsingatækni meira en peir fá tækifæri til og pannig pjálfað færni og pekkingu sem nútímasamfélag krefst af peim.

Með notkun smáforrita gafst nemendum tækifæri til margs konar vinnu með ritaðan texta, myndir og hljóðupptökur. Degar nemendur „léku sér“ notuðu peir um leið tækni- og upplýsingalæsi sitt, p.e. peir notuðu tæknina til samskipta og efnissköpunar, eins og áhersla er lögð á í Aðalnámskrá grunnskóla (Mennta- og menningarmálaráðuneytið, 2013). Niðurstöður gefa til kynna að einfaldleiki í gerð og notendaviðmóti spjaldtölva auðveldi ungum nemendum mjög að nálgast fjölbreyttar textategundir stafrænna miðla, pó að nemendurnir hafi ekki nád fullu valdi á lestri og ritun. Рað er mat höfunda að notkun spjaldtölva á yngsta stigi grunnskóla geti verið góð- 
ur stuðningur við læsi almennt og er pað í samræmi við fyrri niðurstöður og skýrslur um jákvæð áhrif upplýsinga- og samskiptatækni á bekkingu, leikni og hæfni nemenda í námi (Balanskat, 2009; Ómar Örn Magnússon, e.d.; Reykjavíkurborg, 2014; Tamim o.fl., 2015).

Til að efla miðlalæsi purfa nemendur að fá tækifæri til að kanna og búa til fjölbreytt efni par sem reynir á marga pætti miðlunar. Pannig geta peir lært að vinna úr myndrænum upplýsingum á skilvirkan hátt og notað pekkinguna til að birta eigin hugmyndir á marga vegu (Smolin og Lawless, 2003; Stefán Jökulsson, 2012). Meðan vettvangsathuganir stóðu yfir sáust engin dæmi um vinnu par sem nemendur sýndu samnemendum verkefni sín eða birtu pau á vefnum og kennararnir fimm, sem rætt var við, sögðust aldrei hafa unnið á pann hátt með verkefni. Verkefnunum var í flestum tilvikum markaður pröngur rammi og allir fengust við pað sama á sama tíma. Fá tækifæri gáfust til að velja efni eftir áhugasviði og mismunandi miðlum. Kennarar beindu nemendum inn á valdar slóðir á netinu par sem peir gátu skoðað efni, fundið myndir eða fyrirsagnir sem vöktu áhuga peirra og tengdu vinnu peirra og viðfangsefni við raunveruleikann. Slík nálgun er vel til pess fallin að styðja lestur og ritun, auka víðsýni, efla orðaforða og gagnrýna hugsun og efla tækni-, upplýsinga- og miðlalæsi nemenda. Í aðalnámskrá segir að nemendur skuli pjálfast markvisst í upplýsinga- og miðlalæsi frá upphafi skólagöngunnar. Pannig fái peir undirbúning fyrir virka pátttöku í samfélagi par sem alpjóðatengsl, samvinna og samskipti gegna mikilvægu hlutverki (Mennta- og menningarmálaráðuneytið, 2013).

Samskiptamöguleikar sem opnast með spjaldtölvu og aðgengi að neti eru tækifæri sem vert er að skoða frekar og aukið samstarf nemenda milli bæjarfélaga eða jafnvel við nemendur í öðrum löndum getur aukið pekkingu á ólíkri menningu og fjarlægum stöðum. Samkvæmt niðurstöðum var fartæknin ekki notuð til að tengjast umheiminum eða deila efni á samskiptamiðlum, en Fullan (2013) telur mikilvægt að innleiða stafræna tækni í skólastarf með áherslu á breytingar í takt við hnattvæðingu samfélagsins. Aðspurðir sögðu kennarar beggja skólanna skort á práðlausri nettenginu helst hafa staðið í vegi fyrir kennslu sem fæli í sér samvinnu eða tengingu við umheiminn.

Баð felast ýmis tækifæri í að nota samfélagsmiðla með ungum nemendum. Pannig mætti t.d. stofna Twitter-síðu (örblogg) fyrir bekkinn par sem nemendur gætu bloggað daglegar fréttir úr bekkjarstarfinu. Hlutverk bloggara gæeti verið að safna myndum frá starfi dagsins og velja svo úr раð sem peim pætti áhugaverðast eða verkefni sem peir væru stoltir af og vildu deila með öðrum. Баð fælist mikil pjálfun miðlalæsis í pví að purfa að velja lýsandi mynd sem hæfði pví sem nemendur vildu miðla og pað væri áskorun fyrir unga tístara að rita stuttan hnitmiðaðan texta með. Tístarar yrðu að rökstyðja efnisval sitt og sýna kennaranum útfærsluna fyrir birtingu, en einfaldleiki spjaldtölva auðveldar nemendum notkun miðla á vefnum. Með slíkri vinnu mætti einnig efla vitund nemenda um ábyrgðina sem pví fylgir að birta myndir og texta á netinu og setja fram skýrar reglur í pví sambandi. Eftir bví sem nemendur eru yngri er auðveldara að leggja grunn að pví að virða reglur og með markvissu uppeldi að pessu leyti mætti auka líkur á jákvæðri hegðun á netinu pegar fram líða stundir. Við skólapróun á 21. öldinni parf að leggja áherslu á mikilvægi viðhorfsbreytinga og innleiðingu nýrra kennsluhátta sem einkennast m.a. af gagnrýninni hugsun, samvinnu og markvissri notkun upplýsingatækni í námi og kennslu (Fullan og Donnelly, 2013).

Nýjar áherslur í námi og kennslu fela í sér pá hugsun að nám eigi sér stað alla ævi, að allir læri saman og hver af öðrum. Jafnframt er lögð áhersla á að efla beri færni nemenda til að sýna frumkvæði og ábyrgð frá upphafi skólagöngunnar (European Commission, 2018). Niðurstöður sýndu að töluvert var um samvinnu og jafningjafræðslu. Deir sem meira kunnu á spjaldtölurnar voru tilbúnir að deila pekkingu sinni og hjálpa hinum. Рað var einnig greinilegt að nemendur vildu deila verkefnum sínum með öðrum nemendum og fá álit peirra á afurðinni. Fái nemendur tækifæri til að kynna verkefni sín og ræða pau við aðra nemendur getur pað stuðlað að frumkvæði og gagnrýninni hugsun. Með pessu móti má efla upplýsinga- og miðlalæsi sem og tæknilæsi en niðurstöður rannsóknarinnar benda til pess að miðlalæsi á yngsta stigi grunnskólans megi efla enn frekar. 
Degar nemendur fá tækifæri til sköpunar, t.d. með gerð kynninga eða mynda, og miðla svo verkum sínum til annarra efla peir miðlalæsi sitt og slík vinna eflir einnig upplýsinga- og tæknilæsi. Í aðalnámskrá má sjá að almenn notkun tölva og tækninýjunga sem auðvelda aðgengi að netinu er farin að hafa áhrif. Рað birtist m.a. í áherslu á stafrænt læsi, miðlamennt og miðlalæsi og pví að líta beri á tölvur sem öflug tæki sem nýtist til fjölpættrar merkingarsköpunar en ekki einungis ritvinnslu- og reikningsverkfæri (Mennta- og menningarmálaráðuneytið, 2013). Í peirri framtíð sem blasir við nemendum er mikilvægt að peir séu færir um að lesa í og skilja tilgang margs konar textategunda og búi yfir hæfni til að miðla pekkingu og upplýsingum á marga vegu. Dað er pví gott að hefja pjálfun pessara pátta sem fyrst á skólagöngunni og spjaldtölvur henta vel til pess.

\section{Lokaorð}

Samkvæmt rannsóknargögnunum, sem að vísu eru ekki viðamikil og túlka verður með peim fyrirvara, virðist fátt mæla gegn peirri hugmynd að spjaldtölvur geti stutt nám og kennslu á yngsta stigi. Pá ber að hafa í huga að gagna var aflað í umhverfi par sem jákvæð viðhorf ríktu til notkunar spjaldtölva í skólastarfi. Prátt fyrir nýja möguleika sem notkun spjaldtölvanna gefur virðast gögn sem aflað var fyrir pessa rannsókn ekki sýna að kennsluhættir hafi breyst heldur féll notkunin að peim aðferðum sem fyrir voru. Svo virðist sem notkun smáforrita í spjaldtölvum efli upplýsinga- og miðlalæsi og tæknilæsi en að efla purfi enn frekar miðlalæsi með notkun netsins, vefśína og samfélagsmiðla. Í nútímasamfélagi er mikilvægt að styrkja sem best mismunandi tegundir læsis pví stafræn samskiptatækni er mikilvægur páttur í daglegu lífi flestra.

Niðurstöðum pessarar rannsóknar ber að taka með peim fyrirvara að hún tekur aðeins til fimm kennara í tveimur skólum og að ekki var fylgst með hópi nemenda lengur en sem nam einni kennslustund. Đær benda pó til pess að spjaldtölvur geti bætt nám og kennslu með ýmsum hætti. Til dæmis virðist notkun spjaldtölva opna kennurum leið til að auka notkun upplýsingatækni í námi og kennslu á yngsta stigi. Hún virðist einnig geta aukið pátt netsins, vefefnis og samfélagsmiðla í námi ungra nemenda auk pess sem hún veitir aukin tækifæri til að efla upplýsinga- og tækni- og miðlalæsi peirra. Pá er ekki vafi að notkun spjaldtölva eykur fjölbreytni í skólastarfi, t.d. með fjölda smáforrita sem sérstaklega eru gerð til að pjálfa ýmsa færnipætti í námi en einnig með pví hvernig pær einfalda myndatökur, hljóðupptökur, kvikmyndatökur og samsetningu miðlunarpátta. Jafnframt má nefna möguleika spjaldtölvunnar til að halda utan um námsgögn og námsferli - hún getur í peim skilningi nýst sem rafræn námsmappa. Áhugavert er að skoða hvernig nemendur nota spjaldtölvur í einstökum verkefnum en ekki síður hvernig pær nýtast við að halda utan um námsgögn, ferli og afurðir og hvaða áhrif pað hefur á nám. Dað er verðugt rannsóknarefni.

\section{The use of tablet computers in the learning and teaching of first level compulsory school pupils with an emphasis on literacy}

This article is based on data from a qualitative research project conducted in two Reykjavík primary schools in spring 2014. The research objectives are to gain an understanding of the use of tablet computers in early elementary education, focusing on information, media and technology literacy. Cyberspace and digital media play a constantly growing role in most people's daily lives and ICT has strongly influenced culture and social relations. Many see smartphones and tablet computers as the heralds of a new age and believe their inclusion in schoolwork can enrich education and help teachers to meet students' diverse needs, as well as signalling the advent of new priorities in learning and teaching. The use of ICT and, in particular, tablet computers in schoolwork has been the subject of considerable discussion which, among other things, has focused on students' increasingly urgent need for opportunities to use new media at school, since digital communication has become such a prominent part of their lives in general. 
In modern society, digital communication technology is generally seen as an important aspect of daily life. The widespread use of computers and internet-related innovation has strongly impacted the operation of the school and diverse communication potentialities have engendered new types of literacy, for example digital literacy/computer literacy, media literacy and information literacy. The National Curriculum for the Primary School emphasises the need to support literacy in this wider sense and to regard computers as powerful tools for the creation of multiple contexts.

The main objectives of policymakers regarding learning and teaching reflect the debate outlined above. Technology has, for example, transformed the environment of reading and writing; the concept of literacy has acquired a wider meaning and ICT is now envisioned as an integral part of other subjects, thus benefiting students in general. This new reality calls for an urgent transformation in school operations, and many 21 st century educationists and school policy makers emphasise the need for teaching to evolve in step with the rapid transformation of technology and society.

Data were collected in two stages; on the one hand, by field observations during five lessons in the two schools where tablet computers were used and, on the other, by conducting interviews with five supervising teachers after field observations had been completed. Participating schools and teachers were chosen on the basis of their experience involving the use of tablet computers in learning and teaching at the first level of primary school. Both the primary schools added tablet computers to their technical equipment during the winter 2012 to 2013.

The results of this research must be accepted with the reservation that it only includes five teachers in two schools and that a particular student group was not observed for longer than one lesson. Nevertheless, the conclusions suggest that tablet computers can improve learning and teaching in various ways. The use of tablet computers, for example, appears to offer teachers a way to increase the use of ICT in the learning and teaching of the youngest pupils and to provide this group with opportunities to enhance the role of the internet, web-based materials and social media in early elementary education. Tablet computers provide increased potential for strengthening information literacy, media literacy and technology literacy among the youngest pupils, thus adding diversity to schoolwork - for example through the use of miscellaneous small programs specially designed to strengthen various learning skills as well as providing opportunities to simplify photography, sound recording, video filming and the creation of media materials. The introduction of tablet computers into the schools did not appear to alter teaching methods; instead, they were integrated into existing teaching practices.

Key words: Tablet computers, information literacy, media literacy, technology literacy, early elementary education. 


\section{Um höfundana}

Jóhanna Porvaldsdóttir (johanna@arskoli.is) er umsjónarkennari á yngsta stigi í Árskóla á Sauðárkróki. Hún lauk M.Ed.-prófi í menntunarfræði frá kennaradeild Háskólans á Akureyri 2014. Rannsóknin sem pessi grein byggist á var liður í meistaranámi hennar.

Jóhanna hefur starfað við leik- og grunnskóla. Helstu viðfangsefni hennar eru almenn kennsla á yngsta stigi grunnskóla og sérkennsla í stoðpjónustu.

Hermína Gunnpórsdóttir (hermina@unak.is) er dósent við kennaradeild Háskólans á Akureyri. Hún lauk B.A.-prófi í íslensku og uppeldis- og kennslufræði frá Háskóla Íslands, meistaraprófi frá Kennaraháskóla Íslands og doktorsprófi frá Háskóla Íslands. Hermína hefur starfað við leik-, grunn- og framhaldsskóla. Helstu viðfangsefni hennar í kennslu og rannsóknum eru skóli og nám án aðgreiningar, fjölmenning og nám, fötlunarfræði og menntastefna og framkvæmd hennar.

Guðmundur Engilbertsson (ge@unak.is) er lektor við kennaradeild Háskólans á Akureyri. Hann hefur lokið B.Ed.-prófi í kennarafræðum og M.Ed.-prófi í menntunarfræði við HA og er doktorsnemi í menntavísindum við HÍ. Guðmundur hefur starfað við grunn- og tónlistarskóla og hefur um árabil verið ráðgjafi í próunarstarfi í læsi. Helstu viðfangsefni hans í kennslu og rannsóknum lúta að orðaforða, læsi til náms og náms- og kennslufræði.

\section{About the authors}

Jóhanna Porvaldsdóttir (johanna@arskoli.is) is supervisory teacher in early elementary education at Árskóli in Sauðárkrókur. She completed her M.Ed. degree from the University of Akureyri in 2014 and this research was conducted in partial fulfillment of her master's degree. Jóhanna has worked in pre- and primary schools. Her interest is general teaching at early elementary level and additional support for students.

Hermína Gunnpórsdóttir (hermina@unak.is) is associate professor at the University of Akureyri. She holds a B.A. degree in Icelandic, a teaching certification from the University of Iceland, a master's degree from Iceland University of Education and a Ph.D. from the University of Iceland. Her teaching and research interests include inclusive education, multicultural education, disability studies, educational policy and practice.

Guðmundur Engilbertsson (ge@unak.is) is assistant professor at the University of Akureyri. He holds a B.Ed. degree in Education from the University of Akureyri, an M.Ed. degree in Educational studies from the University of Akureyri and is a doctoral student (Ph.D) at the University of Iceland. His teaching and research interests include vocabulary assessment and teaching, literacy for learning, and learning and teaching methods.

\section{Heimildir}

Anna Kristín Sigurðardóttir og Gunnhildur Óskarsdóttir. (2012). Nám og kennsla á yngsta stigi grunnskóla: Einstaklingsmiðun og nýting á námsumhverfi. Rádstefnurit Netlu - Menntakvika. Sótt af http://netla.hi.is/menntakvika2012/001.pdf

Balanskat, A. (2009). Study of the impact of technology in primary schools. Synthesis report. Sótt af http://eacea.ec.europa.eu/ 1lp/studies/documents/study_impact_technology_primary_school/02_synthesis_report_steps_en.pdf

Clark,W. og Luckin, R. (2013). What the research says: iPads in the classroom. Sótt af http://pdf.thepdfportal.com/?id=61713\#

Cohen, L., Manion, L., Morrison, K. og Wyse, D. (2010). A guide to teaching practice (5. útgáfa). London: Routledge.

European Commission. (2013). Survey of schools: ICT in education. Sótt af http://ec.europa.eu/digital-agenda/sites/ digital-agenda/files/KK-31-13-401-EN-N.pdf

European Commission. (2018). Council recommendation on key competences for lifelong learning. Sótt af https://ec.europa.eu/ education/sites/education/files/recommendation-key-competences-lifelong-learning.pdf

Fullan, M. (2007). The new meaning of educational change (4. útgáfa). New York: Teachers College Press.

Fullan, M. (2013). The new pedagogy: Students and teachers as learning partners. Learning Landscapes, 6(2), 23-29. Sótt af http://www.michaelfullan.ca/the-new-pedagogy-students-and-teachers-as-learning-partners/

Fullan, M. og Donnelly, K. (2013). Alive in the swamp: Assessing digital innovations in education. Sótt af http://www.nesta. org.uk/publications/alive-swamp-assessing-digital-innovations-education

Guðrún Gunnarsdóttir. (2015). Skóli 21. aldarinnar. Innleiðing spjaldtölva í grunnskóla Reykjanesbajar (óútgefin meistararitgerð). Sótt af http://hdl.handle.net/1946/21937

Horton, F. W. (2008). Understanding information literacy: A primer. Sótt af http://unesdoc.unesco.org/images/0015/001570/157020e.pdf 
Hrefna Arnardóttir. (2007).Verkfæri, miðill, samskiptatól eða kennari. Netla - Veftímarit um uppeldi og menntun. Sótt af http://netla.hi.is/greinar/2007/019/index.htm

ICT Cluster. (2009). Learning, innovation and ICT: Lessons learned by the ICT cluster education \& training 2010 programme. Sótt af http://www.kslll.net/Documents/Key\%20Lessons\%20ICT\%20cluster\%20final\%20version.pdf

Light, D. og Pierson, E. (2012). Highlighting changes in the classrooms of a successful one-to-one program in rural Argentina: Case studies of Todos los chicos en la red in San Luis. Sótt af http://files.eric.ed.gov/fulltext/ED543158.pdf

Luckin, R., Bligh, B., Manches, A., Ainsworth, S., Crook, C. og Noss, R. (2012). Decoding learning:The proof, promise and potential of digital education. Sótt af http://www.nesta.org.uk/library/documents/DecodingLearningReport_v12.pdf

Mennta- og menningarmálaráđuneytið. (2010). Grunnpættir í menntun. Sótt af http://www.menntamalaraduneyti.is/ media/MRN-pdf-/Grunntattir_i_menntun_juli2010.pdf

Mennta- og menningarmálaráðuneytið. (2013). Aðalnámskrá grunnskóla:Almennur hluti 2011: Greinasvið 2013. Reykjavík: Höfundur.

Ómar Örn Magnússon. (e.d.). Spjaldtölvur í skólastarfi. Sótt af http://reykjavik.is/sites/default/files/ymis_skjol/skjol_utgefid_efni/spjaldtoelvurskolastarfi.pdf

RAND. (2002). Reading for understanding. Toward an R\&D program in reading comprehension. Sótt af http://www. rand.org/pubs/monograph_reports/MR1465.html

Redecker, C., Leis, M., Leendertse, M., Punie,Y., Gijsbers, G., Kirschner, P., ... Hoogveld, B. (2011). The future of learning: Preparing for change. Sótt af http://ftp.jrc.es/EURdoc/JRC66836.pdf

Reykjavíkurborg. (2014). Notkun snjalltækja í skólastarfi. Sótt af http://reykjavik.is/sites/default/files/snjalltaeki_2014.pdf

Schofield, C. P., West,T. og Taylor, E. (2011). Going mobile in executive education: How mobile technologies are changing the executive learning landscape. Sótt af https://www.ashridge.org.uk/website/content.nsf/FileLibrary/C67FAE52 65440F728025798000404608/\$file/ABS_MobileLearning.pdf

Schutt, R. K. (2006). Investigating the social world:The process and practice of research (5. útgáfa). Thousand Oaks: Sage.

Sigurlína Davíðsdóttir. (2013). Eigindlegar eða megindlegar rannsóknaraðferðir? Í Sigríður Halldórsdóttir (ritstjóri), Handbók í aðferðafræði rannsókna (bls. 229-237). Akureyri: Háskólinn á Akureyri.

Silverman, D. (2010). Doing qualitative research. London: Sage.

Smolin, L. I. og Lawless, K. A. (2003). Becoming literate in the technological age: New responsibilities and tools for teachers. The Reading Teacher, 56(6), 570-577.

Snowman, J. og McCow, R. (2012). Psychology applied to teaching (13. útgáfa). Wadsworth: Cengage Learning.

Sólveig Jakobsdóttir, Skúlína H. Kjartansdóttir, Helga Ó. S. Dórormsdóttir og Ragnheiður L. Pálsdóttir. (2012). Spjaldtölvur í Norðlingaskóla - próunarverkefni 2012-2013: Áfangaskýrsla. Sótt af https://skrif.hi.is/rannum/rannsoknir/ utgafa-a-vegum-rannum/

Sólveig Jakobsdóttir, Torfi Hjartarson og Bergpóra Pórhallsdóttir. (2014). Upplýsingatækni í skólastarfi. Í Gerður G. Óskarsdóttir (ritstjóri), Starfshattir í grunnskólum við upphaf 21. aldar (bls. 277-319). Reykjavík: Háskólaútgáfan.

Stefán Jökulsson. (2012). Lasi: Grunnpáttur menntunar. Reykjavík: Mennta- og menningarmálaráđuneyti.

Tablet computer. (2013). Í Encyclopaedia Britannica. Sótt af http://www.britannica.com/EBchecked/topic/1740658/ tablet-computer

Tamim, R. M., Borokhovski, E., Pickup, D., Bernard, R. M. og El Saadi, L. (2015). Tablets for teaching and learning: A systematic review and meta-analysis. Sótt af http://oasis.col.org/handle/11599/1012

Vuorikari, R., Garoia, V. og Balanskat, A. (2011). Introducing netbook pedagogies in schools. Sótt af http://files.eun.org/ netbooks/Acer_Netbook_Study.pdf

Jóhanna Porvaldsdóttir, Guðmundur Engilbertsson og Hermína Gunnpórsdóttir. (2018).

Notkun spjaldtölva í námi og kennslu grunnskólanemenda á yngsta stigi með áherslu á læsi.

Netla - Veftímarit um uppeldi og menntun. Menntavísindasvið Háskóla Íslands.

Sótt af http://netla.hi.is/greinar/2018/styrd/10

https://doi.org/10.24270/netla.2018.10 